\title{
ANALISIS KUALITAS PELAYANAN TERHADAP KEPUASAN PELANGGAN DENGAN MENGGUNAKAN METODE SERVQUAL DI SPBU PASTI PAS MEUREUBO KABUPATEN ACEH BARAT
}

\author{
${ }^{* 1 \mathrm{a}, 1}$ Herdi Susanto, ${ }^{2}$ Fuadri, dan ${ }^{3}$ Yuliani \\ ${ }^{1 a, 2,3}$ Jurusan Teknik Industri, Fakultas Teknik, Universitas Teuku Umar \\ ${ }^{1}$ Jurusan Teknik Mesin, Fakultas Teknik, Universitas Teuku Umar \\ Meulaboh 23681 Aceh Barat, Indonesia \\ *Email: herdisusanto@utu.ac.id
}

\begin{abstract}
ABSTRAK
Purpose of this study is to determine the quality of services in accordance with Standard Operating Procedures (SOP) minimum service standards Pertamina Pasti Pas gas stations and to determine the degree of influence the quality of services provided Pasti Pas Meureubo gas stations to customer satisfaction. Method used to analyze the quality of service to satisfaction costumer is Servqual method which is the method used to measure the quality of service of the attributes of each dimension, so the value will be gap (the gap) is difference between consumer perceptions of the services that have been received with expectations to be received. The measurement method is to measure the quality of service of the attributes of each dimension, so that would be obtained value gap is the difference between consumer perceptions of service received by the consumer expectations on the services that will be received. However, in general there has been no uniformity limitations on the concept of quality servive (servqual). Data analysis Pearson correlation coefficients were processed through a computerized statistical software. Based on the findings of the research data, can be obtained by the correlation coefficient (r) of rhitung of 0, 886 were identified at the level of 0.01 . Based on the statement that if $r>0$, then the hypothesis is accepted and positive direction. Because calculations show that rhitung $\mathrm{r}(0,886)>$ rtabel $(0.198)$, meaning Ha (alternative hypothesis) Ho accepted and rejected. By this it can be seen that customer satisfaction (customers satisfaction) influence on the service "Pasti Pas" Pertamina.
\end{abstract}

Keyword Service Quality, Customer Satisfaction, SPBU Pasti Pas, Meureubo

\section{LATAR BELAKANG}

Kualitas pelayanan adalah suatu strategi dasar bisnis atau spesifikasi yang menghasilkan barang dan jasa yang membuat pelanggan secara mudah terpenuhi kebutuhan dan kepentingannya. Melaui pelayanan yang baik, cepat, teliti dan akurat dapat menciptakan kepuasan dan kesetiaan pelanggan terhadap SPBU yang akhirnya konsumen akan tetap loyal pada SPBU tersebut.

Penelitian sebelumnya dari Karsono (2006) membahas tentang Pengaruh Kualitas Pelayanan terhadap Loyalitas Anggota dengan Kepuasan Pelanggan sebagai Variabel Pemediasi, penelitian ini menggunakan metode Servqual dan bertujuan untuk Meneliti perbedaan antara kualitas pelayanan yang dirasakan (perceive performance) pelanggan dengan kualitas pelayanan yang diharapkan (expectation) pelanggan KPRI UNS dan pengaruhnya 
terhadap kepuasan dan loyalitas anggota. Dengan hasil penelitian yang didapat Membuktikan bahwa kualitas pelayanan berpengaruh positif dan signifikan terhadap loyalitas pelanggan/anggota, ini menunjukkan bahwa semakin baik jasa pelayanan yang diberikan oleh KPRI UNS, maka anggota akan semakin loyal untuk memanfaatkan kembali jasa yang ditawarkan untuk memenuhi kebutuhannya.

Esty Wahyu Pratiwi (2013) membahas tentang Pengaruh Kualitas Pelayanan SPBU Pasti Pas Terhadap Kepuasan Konsumen di Kota Malang penelitian ini dilakukan untuk mengetahui apakah variable kualitas pelayanan yang meliputi bukti fisik, empati, kehandalan, jaminan, dan daya tanggap SPBU Pasti Pas berpengaruh secra parsial atau individu pada setiap variable terhadap kepuasan konsumen di Kota Malang. Dari hasil penelitian didapat Variabel yang berpengaruh dominan terhadap kepuasan konsumen pada SPBU Pasti Pas Jalan Panglima Sudirman kota Malang adalah variabel empati. Karena, kualitas pelayanan dalam hal memberikan salam pada pelanggan serta menanyakan jenis BBM yang dibutuhkan selalu diperhatikan oleh konsumen. Dalam hal empati petugas operator perlu diberikan pengarahan dan terus dilatih agar selalu melayani dengan baik. Serta dalam SPBU tersebut juga menyediakan mekanisme keluhan pelanggan dengan jelas. Sehingga pelanggan merasa dihormati dan dilayani dengan baik oleh petugas operator SPBU tersebut.

SPBU Pasti Pas Meureubo merupakan salah satu SPBU yang berada di Aceh Barat, yang beroperasi sejak tahun 1990, dengan rata-rata pelanggan yang membeli BBM Roda Dua sebanyak 1.053.960 liter/tahun, dan untuk kendaraan roda empat rata-rata pembelian sebanyak 3.767.040 liter/tahun. Hingga saat ini tercatat ada 4 SPBU yg beroperasi di Kabupaten Aceh Barat dan sekaligus menjadi pesaing bagi SPBU Pasti Pas Meureubo ini, yaitu diantaranya SPBU Kuta Padang, SPBU ManekRoo, dan SPBU Suak Raya. Pada SPBU ini terdapat fasilitas yang sesuai dengan Standard Operasional Procedur yaitu mushola, toilet, pos pengisian air radiator dan pompa angin. Kemudian terdapat 5 pos pengisian bahan bakar dengan produk yang ditawarkan seperti premium, pertamax, bio solar dan Pertalite. SPBU tersebut juga terdapat tempat pengisian LPG.

Standar Operasional Prosedur (SOP) Pertamina merupakan SOP yang harus di laksanakan oleh semua SPBU yang ada di wilayah Indonesia, yang menjadi pertanyaan apakah SPBU Pasti Pas Meureubo telah melaksanakan pelayanan sesuai SOP Pertamina, dan bagaimana tingkat kepuasan pelanggan terhadap SPBU ini akan di teliti dalam penelitian ini menggunakan Metode Servqual.

Tujuan penelitian adalah 1). untuk mengetahui kualitas pelayanan yang sesuai dengan Standart Operasional Prosedur (SOP) Pertamina Standar pelayanan Minimal SPBU Pasti Pas. 2). Untuk menentukan besarnya pengaruh kualitas pelayanan yang diberikan SPBU Pasti Pas Meureubo terhadap kepuasan pelanggan.

\section{METODELOGI PENELITIAN}

\subsection{Tempat dan Waktu Pelaksanaan Penelitian}

Penelitian ini dilakukan di SPBU Pasti Pas Meureubo yang merupakan salah satu instasi Persero yang bergerak di bidang barang dan jasa, yang berlokasi di desa Pasi Pinang Kecamatan Meureubo, Kabupaten Aceh Barat, Provinsi Aceh.

\subsection{Populasi dan Sampel Penelitian}

Menurut Juliandi dan Irfan (2013), populasi merupakan totalitas dari seluruh unsur yang ada di dalam sebuah wilayah penelitian. Dalam penelitian ini yang menjadi populasi adalah pelanggan yang mengisi bahan bakar minyak yang jumlahnya tidak diketahui secara pasti. Namun jumlahnya akan diambil melalui teknik sampling. 
Dalam penelitian ini bentuk pengambilan sampel yang digunakan adalah Non Probability Sampling dengan teknik convenience Sampling yaitu dengan maksud dalam penelitian bisa saja terjadi diperolehnya sampel yang tidak direncanakan terlebih dahulu, melainkan secara kebetulan, yaitu unit atau subjek tersedia bagi peneliti saat pengumpulan data dilakukan. Proses diperolehnya sampel semacam ini disebut sebagai penarikan sampel secara kebetulan.

Pada penelitian ini, populasi yang diambil berukuran besar dan jumlahnya tidak diketahui secara pasti. Dalam penentuan sampel, jika populasinya besar dan jumlahnya tidak diketahui, maka digunakan rumus Rao Purba :

$$
n=\frac{z^{2}}{4(M o e)^{2}}
$$

Keterangan:

$\mathrm{n}=$ Ukuran sampel

$\mathrm{z}=$ Tingkat keyakinan yang dalam penentuan sampel 95\% = 1,96

Moe $=$ Margin of error atau kesalahan maksimal yang bisa dikorelasi, disini di tetapkan $100 \%$.

Maka dengan demikian jumlah sampel minimal dapat diambil sebesar:

$$
n=\frac{1,96^{2}}{4(0.10)^{2}}=\frac{1,96^{2}}{0,04}=96,04 \approx 100 \text { sampel }
$$

Berdasarkan perhitungan diatas, maka banyaknya sampel dalam penelitian ini adalah 96,04 yang dibulatkan menjadi 97 responden.

\subsection{Variabel Penelitian}

Penentuan variabel penelitian didasarkan atas studi pendahuluan, studi kepustakaan, dan keadaan SPBU Pasti Pas Meureubo yang berkaitan dengan permasalahan yang ada. Dua jenis varibel penelitian yang akan diamati dalam penelitian ini yaitu:

1. Variabel Independen (Metode servqual)
a. Reliability
Reliability merupakan, atau keandalan yaitu kemampuan perusahaan untuk memberikan pelayanan sesuai yang dijanjikan secara akurat dan terpercaya.
b. Responsiveness
Responsiveness merupakan ketanggapan yaitu suatu kemauan untuk membantu dan memberikan pelayanan yang cepat (responsive) dan tepat kepada pelanggan, dengan penyampaian informasi yang jelas.
c. Assurance
Assurance merupakan jaminan dan kepastian yaitu pengetahuan, kesopan santunan, dan kemampuan para pegawai SPBU .
d. Emphaty
Emphaty yaitu memberikan perhatian yang tulus dan bersifat individual atau pribadi yang diberikan kepada pelanggan dengan berupaya memahami keinginan pelanggan dimana suatu SPBU diharapkan memiliki suatu pengertian dan pengetahuan tentang pelanggan, memahami kebutuhan pelanggan secara spesifik, serta memiliki waktu pengoperasian yang nyaman bagi pelanggan.
e. Tangible
Tangible merupakan bukti fisik yaitu kemampuan SPBU dalam menunjukkan eksistensinya pada pihak eksternal.

2. Variabel Dependen 
Variabel dependen adalah variabel-variabel yang nilainya dipengaruhi atau ditentukan oleh nilai variabel lain. Variabel dependen yang digunakan pada penelitian ini adalah kepuasan pelanggan terhadap pelayanan SPBU Pasti Pas Meureubo. Kepuasan terpenuhi apabila tingkat perasaan seseorang terhadap kinerja/ hasil yang dirasakannya sesuai dengan keinginannya.

\subsection{Rancangan Penelitian}

Rancangan Penelitian dapat dilihat pada blok diagram metodologi penelitian pada Gambar 2.1. Blok Diagram Prosedur Penelitian.

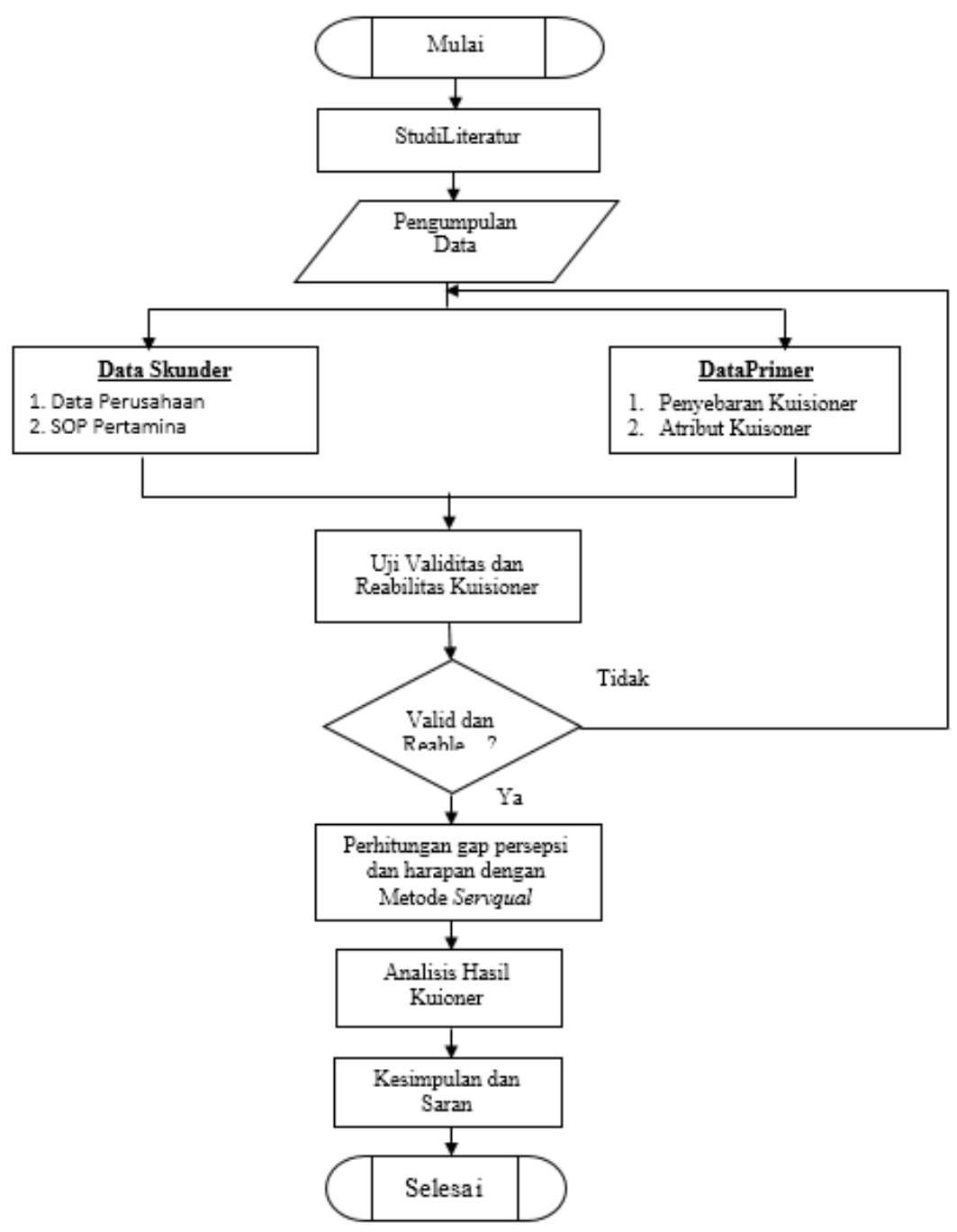

Gambar 2.1. Blok Diagram Prosedur Penelitian

\subsection{Teknik Pengumpulan Data}

Pengumpulan data pada penelitian ini dilakukan dengan cara:

1. Pengumpulan Data Primer

1) Observasi, yaitu kegiatan mengamati secara langsung fenomena yang ada dilapangan yang berkaitan dengan penelitian, seperti melihat bagaimana pelayanan yang diberikan 
pihak SPBU kepada pelanggannya dan melihat apa saja keluhan atau tanggapan pelanggan terhadap pelayanan yang diberikan.

2) Wawancara, yaitu dilakukan kepada tenaga kerja yang bekerja di SPBU Pasti Pas Meureubo untuk mendapatkan data-data yang dibutuhkan.

3) Kuesioner, yaitu memberikan daftar pertanyaan kepada responden yang dilengkapi dengan beberapa alternatif jawaban yang tersedia.

2. Pengumpulan Data Sekunder

Studi kepustakaan, yaitu pengumpulan data dengan menggunakan buku, jurnal, skripsi, internet dan laporan penelitian yang berkaitan dengan objek penelitian yang diperoleh dari dokumen perusahaan.

\subsection{Teknik Analisis Data}

Teknik analisis data adalah cara yang digunakan untuk menjawab rumusan masalah atau menguji hipotesis. Penelitian ini menggunakan metode kuantitatif, maka teknik analisis data menggunakan metode statistik yang sudah tersedia (Sugiyono, 2012 :426). Adapun metode statistik yang digunakan adalah sebagai berikut:

2.6.1. Uji Validitas

Uji validitas digunakan untuk mengukur sah atau tidaknya suatu kuesioner. Suatu dikatakan sah jika pertanyaan pada kuesioner mampu mengungkapkan sesuatu yang akan diukur oleh kuesioner tersebut, untuk mengukur $r$ hitung menggunakan persamaan 3.2. Uji validitas dilakukan dnegan membandingkan nilai $r$ tabel untuk degree of freedom $(d f)=n-k$, dengan alpha 0,05 dalam hal ini $\mathrm{n}$ adalah jumlah sampel dan k adalah jumlah item. Jika $r$ hitung $>r$ tabel, maka pertanyaan tersebut dikatakan valid (Ghozali, 2005).

\subsubsection{Uji Reabilitas}

Uji reabilitas merupakan alat untuk mengukur suatu kuesioner yang merupaka indikator dari variabel atau konstruk, untuk mengukur Reabilitas menggunakan persamaan 3.3. Suatu kuesioner dikatakan reliable atau handal jika jawaban seseorang terhadap pertanyaan konsisten atau stabil dari waktu ke waktu. SPSS memberikan fasilitas untuk mengukur reliabilitas dengan uji statistik cronbach alpha (a). Suatu variabel dikatakan 1 reliable jika memberikan nilai cronbach alpha > 0,60 (Ghozali, 2005).

\subsubsection{Gap kepuasan dan Harapan}

Perbedaan antara persepsi dan ekspektasi merupakan gap atau kesenjangan. Jika gap bernilai positif berarti pelanggan merasa puas, sedangkan jika bernilai negatif berarti pelanggan merasa kurang puas. Analisis gap ditujukan untuk mengetahui faktor-faktor yang harus diprioritaskan karena memiliki gap performansi negatif yang tinggi. Dalam hal ini ada langkahlangkah dalam perhitungan gap persepsi dan ekspektasi yaitu :

1. Perhitungan total nilai tingkat pelayanan dalam variable kepuasan

2. Perhitungan nilai Mean dan Modus dari setiap variabel kebutuhan

3. Perhitungan gap (kesenjangan) antara tingkat pelayanan dengan tingkat kepentingan

\subsection{Analisis dan Evaluasi}

Analisis dan Evaluasi dari hasil penelitian maka yang dilakukan adalah sebagai berikut:

1. Analisis hasil pembagian kuisioner penelitian yang telah dibagikan untuk mengetahui keinginan pelanggan tentang pelayanan yang di berikan pihak SPBU Pasti Pas Meureubo.

2. Besar gap antara persepsi dan harapan pelanggan dapat dilihat dari besarnya selisih antara kedua variabel tersebut.

\section{HASIL DAN PEMBAHASAN}




\subsection{Standar Pelayanan SPBU Pasti Pas Meureubo}

Tabel 3.1.Perbandingan Standar Fasilitas Pertamina dengan SPBU Meureubo

\begin{tabular}{|c|c|c|c|}
\hline No & Standar Pertamina & Standar Meureubo & $\begin{array}{c}\text { Jumlah } \\
\text { Unit }\end{array}$ \\
\hline 1 & Sarana pemadam kebakaran & $\begin{array}{ll}\text { Sarana } & \text { pemadam } \\
\text { kebakaran } & \end{array}$ & 7 \\
\hline 2 & Instalasi pengolahan limbah & $\begin{array}{l}\text { Instalasi } \quad \text { pengolahan } \\
\text { limbah }\end{array}$ & 1 \\
\hline 3 & $\begin{array}{l}\text { Instalasi Oil Cather dan well } \\
\text { Cather }\end{array}$ & $\begin{array}{l}\text { Instalasi Oil Cather dan } \\
\text { well Cather }\end{array}$ & 1 \\
\hline 4 & Instalasi sumur pantau & Instalasi sumur pantau & 1 \\
\hline 5 & Saluran Drainase & Saluran Drainase & 1 \\
\hline 6 & $\begin{array}{l}\text { Memiliki pipa ventilasi } \\
\text { tangki pendam }\end{array}$ & $\begin{array}{l}\text { Memiliki pipa ventilasi } \\
\text { tangki pendam }\end{array}$ & 1 \\
\hline 7 & $\begin{array}{l}\text { memiliki dinding pembatas } \\
\text { pengaman }\end{array}$ & $\begin{array}{l}\text { memiliki dinding pembatas } \\
\text { pengaman }\end{array}$ & 5 \\
\hline 8 & $\begin{array}{l}\text { terdapat rambu-rambu tanda } \\
\text { peringatan }\end{array}$ & $\begin{array}{l}\text { terdapat rambu-rambu } \\
\text { tanda peringatan }\end{array}$ & 5 \\
\hline 9 & Memliki lampu penerangan & Memliki lampu penerangan & 10 \\
\hline 10 & Papan petunjuk SPBU & Papan petunjuk SPBU & 7 \\
\hline 11 & Pompa & Pompa & 6 \\
\hline 12 & Pulau pompa & Pulau pompa & 5 \\
\hline 13 & Dulker & Dulker & 1 \\
\hline 14 & Sensor api & - & - \\
\hline 15 & toilet & toilet & 4 \\
\hline 16 & mushola & mushola & 1 \\
\hline 17 & lahan parkir & lahan parkir & 1 \\
\hline 18 & listrik dan air yang memadai & $\begin{array}{l}\text { listrik dan air yang } \\
\text { memadai }\end{array}$ & 2 \\
\hline 19 & Rambu Dilarang merokok & Rambu Dilarang merokok & 1 \\
\hline 20 & $\begin{array}{l}\text { Rambu Dilarang menggunakan } \\
\text { telepon seluler }\end{array}$ & $\begin{array}{l}\text { Rambu Dilarang menggunakan } \\
\text { telepon seluler }\end{array}$ & 1 \\
\hline
\end{tabular}


22 Rambu tata cara menggunakan

Rambu tata cara menggunakan alat pedam kebakaran alat pedam kebakaran

\subsection{Hasil Uji Validitas dan Reliabilitas}

Sebelum daftar pertanyaan diberikan kepada responden, daftar pertanyaan tersebut perlu di uji terlebih dahulu. Pengujian Validitas dan reliabilitas instrumen dilakukan pada 97 responden semua pelanggan SPBU Pasti Pas Meureubo Kabupaten Aceh Barat.

\subsubsection{Validitas}

Uji validitas akan dilakukan pada hasil rekapitulasi data penilaian terhadap unsur-unsur kualitas pelayanan, yaitu tangible, reability, responsibility, assurance dan emphaty dengan metode Product Moment, maka dapat diketahui bahwa semua variabel yang diteliti menghasilkan korelasi lebih besar dari pada nilai $\mathrm{r}$ tabel pada $\alpha=5 \%$ dan $\mathrm{N}=97$ pada penilaian kusioner.

Perhitungan uji Validitas variable 1 dengan menggunakan persamaan Product Moment sebagai berikut :

$$
r=\frac{N\left(\sum X Y\right)-\left(\sum X \sum Y\right)}{\sqrt{\left\{N \sum X^{2}-\left(\sum X\right)^{2}\right\}\left\{N \sum Y^{2}-\left(\sum Y\right)^{2}\right\}}}
$$

Berikut ini adalah tabel hasil rekapitulasi pengujian validitas persepsi untuk penilaian kuisioner dapat dilihat pada tabel berikut ini:

a. Rekapitulasi Validitas Persepsi

Tabel 3.6. Rekapitulasi pengujian validitas persepsi untuk penilaian kuisioner

\begin{tabular}{|c|c|c|c|c|c|}
\hline Variabel & No & Pernyataan & r Hitung & $r$ tabel & Ket \\
\hline \multirow{2}{*}{$\begin{array}{l}\text { Tangibel } \\
\text { (Berwujud) }\end{array}$} & 1 & $\begin{array}{l}\text { Kebersihan toilet dapat digunakan } \\
\text { dengan nyaman oleh pelanggan }\end{array}$ & 0.476 & 0.198 & Valid \\
\hline & 2 & $\begin{array}{l}\text { Ketaatan Karyawan / operator dalam } \\
\text { menggunakan seragam }\end{array}$ & 0.653 & 0.198 & Valid \\
\hline \multirow{2}{*}{$\begin{array}{l}\text { Reliability } \\
\text { (Keandalan) }\end{array}$} & 3 & $\begin{array}{l}\text { Kemampuan SPBU menyediakan BBM } \\
\text { dengan mutu Standar Pertamina }\end{array}$ & 0.776 & 0.198 & Valid \\
\hline & 4 & $\begin{array}{l}\text { Menyediakan BBM dengan takaran } \\
\text { yang tepat (pasti pas) }\end{array}$ & 0.409 & 0.198 & Valid \\
\hline \multirow{3}{*}{$\begin{array}{c}\text { Responsivene } \\
\text { ss } \\
\text { (Daya } \\
\text { tangkap) }\end{array}$} & 5 & Pelayanan Operator SPBU yang cepat & 0.232 & 0.198 & Valid \\
\hline & 6 & $\begin{array}{l}\text { Memberikan kembalian uang dengan } \\
\text { pas }\end{array}$ & 0.677 & 0.198 & Valid \\
\hline & 7 & $\begin{array}{lccr}\text { Kemauan } & \text { karyawan } & \text { SPBU } & \text { untuk } \\
\text { membantu } & \text { pelanggan } & \text { yang } & \text { sedang } \\
\text { kesulitan } & & & \end{array}$ & 0.688 & 0.198 & Valid \\
\hline $\begin{array}{l}\text { Assurance } \\
\text { (Jaminan) }\end{array}$ & 8 & $\begin{array}{l}\text { Kemampuan operator menjamin } \\
\text { kemurnian BBM }\end{array}$ & 0.314 & 0.198 & Valid \\
\hline
\end{tabular}




$\begin{array}{lclllll} & 9 & \begin{array}{l}\text { Kesopanan dan kemampuan Operator } \\ \text { SPBU ketika memberikan pelayanan }\end{array} & 0.807 & 0.198 & \text { Valid } \\ & 10 & \begin{array}{l}\text { Kemampuan dalam pengisian BBM } \\ \text { dimulai dari angka nol }\end{array} & 0.378 & 0.198 & \text { Valid } \\ \text { Emphaty } & 11 & \begin{array}{l}\text { Keramahan operator SPBU dalam } \\ \text { melayani pelanggan dengan senyum, 0.400 } \\ \text { sapa dan salam }\end{array} & 0.198 & \text { Valid } \\ \text { (Kepedulian) } & 12 & \begin{array}{l}\text { Operator SPBU menanyakan kepada } \\ \text { pelangan akan membeli produk apa } \\ \text { dan berapa }\end{array} & & 0.459 & 0.198 & \text { Valid }\end{array}$

\section{Sumber: Hasil Pengolahan Data SPSS, 2016}

Berdasarkan tabel 3.6.diatas hasil rekapitulasi pengujian validitas untuk Persepsi dapat diketahui bahwa tiap butir pertanyaan yang masing-masing nilainya lebih besar dari pada nilai $\mathrm{r}$ tabel. Nilai $r$ hitung yang terbesar adalah pada pertanyaan Kemampuan SPBU menyediakan BBM dengan mutu Standar Pertamina dengan nilai $r$ hitung sebesar 0,776 yang mana lebih besar dari pada nilai $\mathrm{r}$ tabel product moment yaitu sebesar 0,198 sehingga dapat disimpulkan bahwa hasil pengujian dinyatakan valid (data dapat diterima).

b. Rekapitulasi Validasi Harapan

Tabel 3.7. Rekapitulasi pengujian validitas harapan untuk penilaian kuisioner

\begin{tabular}{|c|c|c|c|c|c|}
\hline Variabel & No & Pernyataan & r Hitung & r tabel & Ket \\
\hline \multirow{2}{*}{$\begin{array}{l}\text { Tangibel } \\
\text { (Berwujud) }\end{array}$} & 1 & $\begin{array}{l}\text { Saya merasa puas Kebersihan toilet } \\
\text { dapat digunakan dengan nyaman oleh } \\
\text { pelanggan }\end{array}$ & 0.314 & 0.198 & Valid \\
\hline & 2 & $\begin{array}{l}\text { Saya merasa puas Ketaatan Karyawan / } \\
\text { operator dalam menggunakan seragam }\end{array}$ & 0.863 & 0.198 & Valid \\
\hline \multirow{2}{*}{$\begin{array}{l}\text { Reliability } \\
\text { (Keandalan) }\end{array}$} & 3 & $\begin{array}{l}\text { Saya merasa puas Kemampuan SPBU } \\
\text { menyediakan BBM dengan mutu } \\
\text { Standar Pertamina }\end{array}$ & 0.776 & 0.198 & Valid \\
\hline & 4 & $\begin{array}{l}\text { Saya merasa puas Menyediakan BBM } \\
\text { dengan takaran yang tepat (pasti pas) }\end{array}$ & 0.769 & 0.198 & Valid \\
\hline \multirow{3}{*}{$\begin{array}{c}\text { Responsivenes } \\
\text { s } \\
\text { (Daya } \\
\text { tangkap) }\end{array}$} & 5 & $\begin{array}{l}\text { Saya merasa puas Pelayanan Operator } \\
\text { SPBU yang cepat }\end{array}$ & 0.460 & 0.198 & Valid \\
\hline & 6 & $\begin{array}{l}\text { Saya merasa puas Operator } \\
\text { Memberikan kembalian uang dengan } \\
\text { pas }\end{array}$ & 0.663 & 0.198 & Valid \\
\hline & 7 & $\begin{array}{l}\text { Saya merasa puas Kemauan karyawan } \\
\text { SPBU untuk membantu pelanggan } \\
\text { yang sedang kesulitan }\end{array}$ & 0.518 & 0.198 & Valid \\
\hline Assurance & 8 & Saya merasa puas & 0.586 & 0.198 & Valid \\
\hline
\end{tabular}


(Jaminan)

Emphaty

(Kepedulian) operator menjamin kemurnian BBM

Saya merasa puas Kesopanan dan

kemampuan Operator SPBU ketika

memberikan pelayanan

0.500

0.198

Valid

Saya merasa puas Kemampuan dalam

10 pengisian BBM dimulai dari angka nol

0.567

0.198

Valid

Saya merasa puas Keramahan operator

SPBU dalam melayani pelanggan

dengan senyum, sapa dan salam

0.459

0.198

Valid

Saya merasa puas Operator SPBU menanyakan kepada pelanggan akan membeli produk apa dan berapa
0.590

0.198

Valid

\section{Sumber: Hasil Pengolahan Data SPSS}

Dari tabel tersebut terlihat bahwa $\mathrm{r}$ product moment untuk penilaian kinerja pada masing-masing butir pertanyaan dengan rhitung $>\mathrm{r}$ tabel yang berarti butir-butir kuesioner untuk dimensi kesigapan, empati, bukti fisik, kehandalan, dan jaminan adalah dapat dinyatakan valid (sah).

\subsubsection{Reliabilitas}

Untuk melakukan pengujian digunakan rumus Alpha Cronbach. Uji reliabilitas dilakukan untuk mengetahui sejauhmana hasil pengukurankuesioner yang digunakan relatif konsisten bila dilakukan pengukuran dua kaliatau lebih pada responden yang berbeda. Reliabilitas kuesioner berkaitan dengan skor hasil pengukuran terbebas dari kesalahan pengukuran.Sehingga hasil perhitungan uji reliabilitas untuk tiap-tiap butir pertanyaan pada item kuesioner Tingkat Kinerja dan Harapan akan ditampilkan di dalam tabel dibawah ini:

$r_{11}=\left[\frac{K}{K-1}\right]\left[1-\frac{\sum \sigma^{2}}{\sigma_{t}{ }^{2}}\right]$.

Tabel 3.8. Rekapitulasi Uji Reliabilitas Tingkat Kuisioner

\begin{tabular}{clcccc}
\hline No & \multicolumn{3}{c}{ Variabel } & Nilai Alpha Cronbach & Ket \\
\hline $\mathbf{1}$ & $\begin{array}{l}\text { Persepsi } \\
\text { pelayanan }\end{array}$ & terhadap & Kualitas & 0.72 & Realibel \\
\hline $\mathbf{2}$ & $\begin{array}{l}\text { Harapan } \\
\text { pelayanan }\end{array}$ & terhadap & Kualitas & 0.82 & Realibel \\
\hline
\end{tabular}

\section{Sumber: Hasil Pengolahan Data SPSS}

Hal ini menunjukkan bahwa pengukuran terhadap variabel penelitian ini telah reliabel dan dapat memberikan hasil yang konsisten, Nilai koefisien reliabilitas harapan mahasiswa sebesar 0,72 .

Karena nilai $r$ hitung $>0,60$ dan $r$ hitung $>\mathrm{r}$ tabel, maka data Persepsi dan harapan pelanggan SPBU Meureubo dinyatakan reliabel dan disimpulkan bahwa kuesioner Persepsi dan harapan pelanggan SPBU Meureubo yang digunakan adalah reliabel dalam arti dapat dipercaya kebenaran datanya.

\subsection{Gap (Kesenjangan) Persepsi dan Harapan}

4.4.1. Pengolahan Data Persepsi dan Harapan 
Pengolahan data kuesioner pada bagian ini bertujuan untuk mengetahui tingkat penilaian pelanggan SPBU Pasti Pas Meureubo Kabupaten Aceh Barat. Penilaian tingkat pelayanan ini diperoleh berdasarkan pada hasil kuesioner tertutup. Untuk mendapatkan tujuan ini maka sebagai langkah pertama adalah melakukan perhitungan total nilai pelayanan setiap variabel kebutuhan dan dilanjutkan dengan perhitungan nilai mean dan modus untuk setiap variabel kebutuhan tersebut. Nilai mean dan modus inilah yang menggambarkan tingkat pelayanan SPBU Pasti Pas Meureubo Kabupaten Aceh Barat terhadap pelanggannya.

Nilai skala Likert untuk tingkat pelayanan tersebut adalah sebagai berikut :

SS $\quad=$ Sangat Setuju $=5$

$\mathrm{S} \quad=$ Setuju $=4$

KS $\quad=$ Kurang Setuju $\quad=3$

TS = Tidak Setuju $\quad=2$

STS = Sangat Tidak Setuju $=1$

Maka total nilai pelayanan untuk variabel 1 adalah :

Total nilai pelayanan $\quad=$ responden $\mathrm{SB} \times($ nilai $\mathrm{SB})+$ responden $\mathrm{B} \times$ (nilai $\mathrm{B}$ ) responden $\mathrm{CB} \times($ nilai $\mathrm{CB})+$ responden $\mathrm{KB} \times($ nilai $\mathrm{KB})+$ responden TB $x$ (nilai TB)

Hasil perhitungan total nilai pelayanan dari setiap variabel pelayanan dapat dilihat pada Tabel 3.9.

\subsubsection{Analisis Skor Index Responden}

Analisis ini dilakukan untuk mendapatkan gambaran deskriptif mengenai responden penelitian ini, khususnya variabel-variabel penelitian yang digunakan. Dalam penelitian ini, kuesioner yang dibagikan menggunakan skala Likert. Maka perhitungan indeks jawaban responden dilakukan dengan rumus sebagai berikut :

Nilai Indeks $=((F 1 \times 1)+(F 2 \times 2)+(F 3 \times 3)+(F 4 \times 4)+(F 5 \times 5) / 5$

Dimana : F1 adalah frekuensi jawaban responden yang menjawab 1.F2 adalah frekuensi jawaban responden yang menjawab 2. F3 adalah frekuensi jawaban responden yang menjawab 3. Dan seterusnya hingga F5 untuk menjawab 5 skor yang digunakan dalam kuesioner penelitian ini.

Pada kuesioner penelitian ini, angka jawaban responden tidak dimulai dari angka 0 , melainkan dari angka 1 hingga 5. Oleh karena itu angka indeks yang dihasilkan akan dimulai dari angka 20 hingga 100 dengan rentang 80. Dalam penelitian ini digunakan kriteria 3 kotak (three box method), maka rentang sebesar 80 akan dibagi 3 dan menghasilkan rentang sebesar 26,67. Rentang tersebut akan digunakan sebagai dasar untuk menentukan indeks persepsi konsumen terhadap variabel-variabel yang digunakan dalam penelitian ini (Ferdinand, 2006:292), yaitu sebagai berikut :

$73,36-100,00=$ Tinggi

$46,68-73,35=$ Sedang

$20,00-46,67=$ Rendah

a. Nilai persepsi dari setiap variable pelayanan

Tabel 3.9.Total Nilai Persepsi SPBU Pasti Pas Meureubo

\begin{tabular}{llcccccccc}
\hline No & Variabel & SS & S & KS & TS & STS & Jmlh & Indeks & Kriteria \\
\hline $\mathbf{1}$ & Tangibel 1 & 14 & 72 & 7 & 4 & 0 & 387 & 77,4 & Tinggi \\
$\mathbf{2}$ & Tangibel 2 & 46 & 41 & 9 & 1 & 0 & 423 & 84,6 & Tinggi
\end{tabular}




\begin{tabular}{llcccccccc}
$\mathbf{3}$ & Reliability 1 & 43 & 45 & 8 & 1 & 0 & 421 & 84,2 & Tinggi \\
$\mathbf{4}$ & Reliability 2 & 37 & 47 & 11 & 2 & 0 & 410 & 82 & Tinggi \\
$\mathbf{5}$ & Responsiveness 1 & 24 & 50 & 20 & 2 & 1 & 371 & 74,2 & Tinggi \\
$\mathbf{6}$ & Responsiveness 2 & 29 & 59 & 8 & 1 & 0 & 407 & 81,4 & Tinggi \\
$\mathbf{7}$ & Responsiveness 3 & 30 & 54 & 10 & 3 & 0 & 402 & 80,4 & Tinggi \\
$\mathbf{8}$ & Assurance 1 & 30 & 41 & 24 & 1 & 1 & 389 & 77,8 & Tinggi \\
$\mathbf{9}$ & Assurance 1 & 48 & 41 & 8 & 0 & 0 & 428 & 85,6 & Tinggi \\
$\mathbf{1 0}$ & Assurance 1 & 22 & 65 & 9 & 0 & 1 & 398 & 79,6 & Tinggi \\
$\mathbf{1 1}$ & Emphaty 1 & 15 & 68 & 13 & 1 & 0 & 388 & 77,6 & Tinggi \\
$\mathbf{1 2}$ & Emphaty 1 & 22 & 70 & 4 & 1 & 0 & 404 & 80,8 & Tinggi \\
\hline
\end{tabular}

\section{Sumber: Hasil Pengolahan Data Kuesioner}

Berdasarkan dari data table di atas, dapat kita lihat bahwa nilai indeks dari total nilai persepsi setiap variable pelayanan mendapat nilai indeks yang besar dengan kata lain kriteria yang didapat pada tiap butir variabel dengan kriteria tinggi. Untuk indeks tertinggi pada variable Assurance dengan pertanyaan Kesopanan dan kemampuan operator ketika memberikan pelayanan didapat indeks sebesar 85,6.

b. Nilai harapan dari setiap variable pelayanan

Tabel 3.10. Total Nilai Harapan SPBU Pasti Pas Meureubo

\begin{tabular}{llcccccccc}
\hline No & \multicolumn{1}{c}{ Variabel } & SS & S & KS & TS & STS & Jmlh & Indeks & Kriteria \\
\hline $\mathbf{1}$ & Tangibel 1 & 66 & 23 & 6 & 2 & 0 & 444 & 88,8 & Tinggi \\
$\mathbf{2}$ & Tangibel 2 & 48 & 42 & 7 & 0 & 0 & 429 & 85,8 & Tinggi \\
$\mathbf{3}$ & Reliability 1 & 44 & 45 & 7 & 1 & 0 & 423 & 84,6 & Tinggi \\
$\mathbf{4}$ & Reliability 2 & 46 & 44 & 7 & 0 & 0 & 427 & 85,4 & Tinggi \\
$\mathbf{5}$ & Responsiveness 1 & 14 & 55 & 28 & 0 & 0 & 374 & 74,2 & Tinggi \\
$\mathbf{6}$ & Responsiveness 2 & 31 & 58 & 7 & 1 & 0 & 410 & 82 & Tinggi \\
$\mathbf{7}$ & Responsiveness 3 & 28 & 53 & 14 & 2 & 0 & 398 & 79,6 & Tinggi \\
$\mathbf{8}$ & Assurance 1 & 25 & 40 & 30 & 2 & 0 & 379 & 75,8 & Tinggi \\
$\mathbf{9}$ & Assurance 2 & 37 & 47 & 11 & 2 & 0 & 410 & 82 & Tinggi \\
$\mathbf{1 0}$ & Assurance 3 & 15 & 68 & 12 & 2 & 0 & 387 & 77,4 & Tinggi \\
$\mathbf{1 1}$ & Emphaty 1 & 12 & 68 & 17 & 0 & 0 & 393 & 78,6 & Tinggi
\end{tabular}


12 Emphaty 2

$$
\begin{array}{lllll}
12 & 61 & 21 & 3 & 0
\end{array}
$$

$373 \quad 74,6$

Tinggi

Sumber: Hasil Pengolahan Data

Berdasarkan dari data table di atas, dapat kita lihat bahwa nilai indeks dari total nilai persepsi setiap variable pelayanan mendapat nilai indeks yang besar dengan kata lain kriteria yang didapat pada tiap butir variabel dengan kriteria tinggi. Untuk indeks tertinggi pada variable Tangible dengan pertanyaan saya merasa puas kebersihan toilet dapat digunakan dengan nyaman oleh pelanggan didapat indeks sebesar 88,8.

4.4.2. Gap Tingkat Kepuasan dan Harapan pelanggan

Dari hasil pengolahan data kuesioner pelanggan SPBU untuk tigkat pelayanan dan tingkat kepentingan pelanggan SPBU terhadap pelayanan SPBU Pasti Pas Meureubo Kabupaten Aceh Barat diperoleh gambaran adanya gap antara tingkat pelayanan dan tingkat kepuasan pelanggan SPBU di SPBU Pasti Pas Meureubo Kabupaten Aceh Barat. Gap ini menunjukkan bahwa pelayanan SPBU Pasti Pas Meureubo Kabupaten Aceh Barat pada suatu variabel tidak sesuai dengan harapan pelanggan SPBU. Untuk mengetahui gap ini, digunakan nilai rata-rata dari tingkat kepentingan dan tingkat pelayanan dari setiap variabel kebutuhan tersebut.

Untuk variabel 1, nilai gap-nya sebesar : Gap 1 = rata-rata nilai persepsi 1 - rata-rata nilai harapan 1, nilai gap untuk variabel 1 adalah sebesar -0,59. Nilai-nilai untuk setiap variabel dapat dilihat pada Tabel 3.11.

Tabel 3.11. Nilai Gap Tingkat Pelayanan dan Tingkat Kepentingan

\begin{tabular}{llccc}
\hline No & Variabel & Mean Persepsi & $\begin{array}{c}\text { Mean } \\
\text { Harapan }\end{array}$ & Gap \\
\hline $\mathbf{1}$ & Tangibel 1 & 3.99 & 4.58 & -0.61 \\
$\mathbf{2}$ & Tangibel 2 & 4.36 & 4.42 & -0.06 \\
$\mathbf{3}$ & Reliability 1 & 4.34 & 4.36 & -0.02 \\
$\mathbf{4}$ & Reliability 2 & 4.23 & 4,40 & -0.17 \\
$\mathbf{5}$ & Responsiveness 1 & 3.82 & 3.86 & -0.04 \\
$\mathbf{6}$ & Responsiveness 2 & 4.20 & 4.23 & -0.03 \\
$\mathbf{7}$ & Responsiveness 3 & 4.14 & 4.10 & 0.04 \\
$\mathbf{8}$ & Assurance 1 & 4.01 & 3.91 & 0.01 \\
$\mathbf{9}$ & Assurance 2 & 4.41 & 4.23 & 0,18 \\
$\mathbf{1 0}$ & Assurance 3 & 4.10 & 3.99 & 0.11 \\
$\mathbf{1 1}$ & Emphaty 1 & 4.00 & 4.05 & -0.05
\end{tabular}




\section{Sumber: Hasil Pengolahan Data}

Sedangkan perbedaan ( gap )yang terjadi antara nilai persepsi dan harapan dapat dilihat pada gambar grafik dibawa ini :

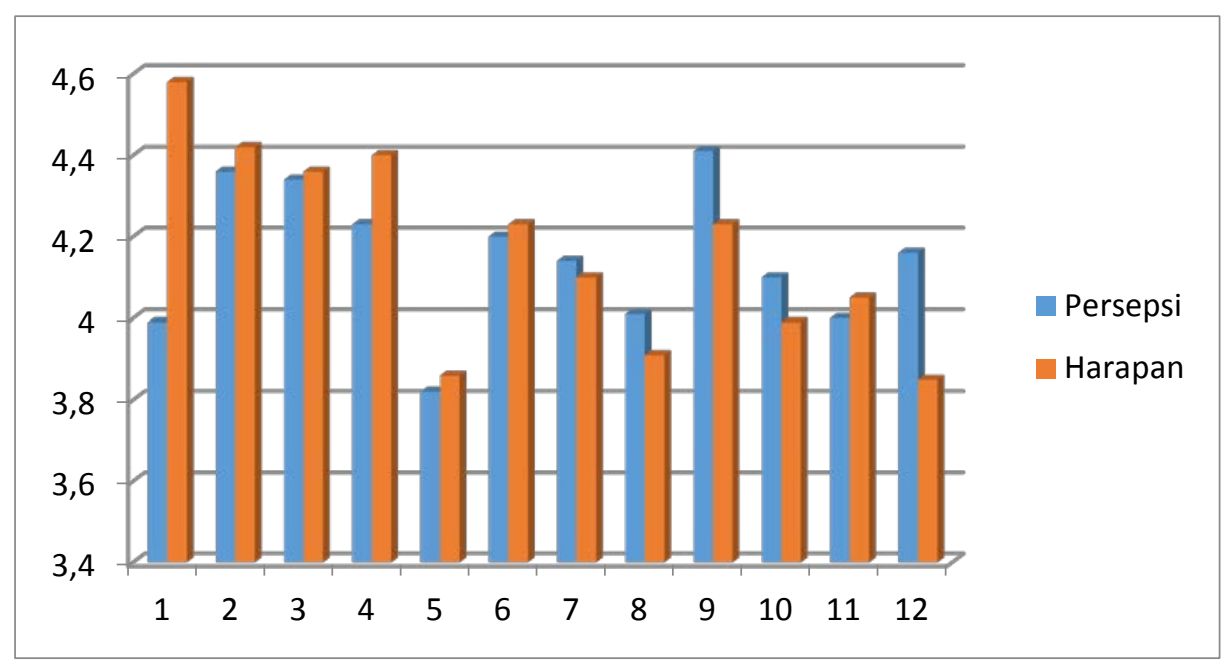

Gambar 3.4. Kesenjangan (Gap) antara Persepsi dan Harapan pelanggan

\subsection{Analisis Statistik}

\subsubsection{Regresi Linier Berganda}

Analisis regresi linier berganda digunakan dalam penelitian ini dengan tujuan untuk membuktikan hipotesis mengenai pengaruh variabel dimensi-dimensi kualitas pelayanan secara parsial maupun secara bersama-sama terhadap kepuasan konsumen. Perhitungan statistik dalam analisis regresi linier berganda yang digunakan dalam penelitian ini adalah dengan menggunakan bantuan program komputer SPSS for Windows versi 17.0. Hasil pengolahan data dengan menggunakan program SPSS selengkapnya ada pada lampiran dan selanjutnya dijelaskan pada Tabel 3.12 berikut ini :

Tabel 3.12. Coefficients ${ }^{\mathrm{a}}$

\begin{tabular}{|c|c|c|c|c|c|c|c|c|}
\hline & \multirow{2}{*}{ Model } & \multicolumn{2}{|c|}{$\begin{array}{l}\text { Unstandardized } \\
\text { Coefficients }\end{array}$} & $\begin{array}{l}\text { Standardize } \\
\mathrm{d} \\
\text { Coefficients }\end{array}$ & \multirow{2}{*}{$\mathrm{t}$} & \multirow{2}{*}{ Sig. } & \multicolumn{2}{|c|}{ Correlations } \\
\hline & & B & $\begin{array}{l}\text { Std. } \\
\text { Error }\end{array}$ & Beta & & & $\begin{array}{l}\text { Zero- } \\
\text { order }\end{array}$ & $\begin{array}{c}\text { Partia } \\
\quad \text { Part }\end{array}$ \\
\hline \multirow[t]{2}{*}{1} & (Constant) & 1.742 & 2.942 & & .592 & .555 & & \\
\hline & Tangible & .475 & .300 & 100 & 1.580 & .118 & .602 & 077. 163. \\
\hline
\end{tabular}




\begin{tabular}{lccccccc} 
Reliability & 1.984 & .225 & .504 & 8.831 & .000 & .751 & .679 .429 \\
Responsive & .926 & .184 & .276 & 5.023 & .000 & .544 & .466 .244 \\
Assurance & .704 & .220 & .198 & 3.195 & .002 & .624 & .318 .155 \\
Emphaty & .864 & .267 & .171 & 3.230 & .002 & .429 & .321 .157 \\
\hline
\end{tabular}

a. Dependent Variable: Harapan

Model persamaan regresi yang dapat dituliskan dari hasil tersebut dalam bentuk persamaan regresi sebagai berikut :

$$
\mathrm{Y}=1,742+0,475 \mathrm{X} 1+1,984 \mathrm{X} 2+0,926 \mathrm{X} 3+0,704 \mathrm{X} 4+0,864 \mathrm{X} 5
$$

Persamaan regresi tersebut dapat dijelaskan sebagai berikut :

a. Koefisien regresi variabel bukti fisik (tangible) mempunyai arah positif dalam pengaruhnya terhadap kepuasan konsumen.

b. Koefisien regresi variabel keandaan (reliability) mempunyai arah positif dalam pengaruhnya terhadap kepuasan konsumen.

c. Koefisien regresi variabel daya tanggap (responsiveness) mempunyai arah positif dalam pengaruhnya terhadap kepuasan konsumen.

d. Koefisien regresi variabel jaminan (assurance) mempunyai arah positif dalam pengaruhnya terhadap kepuasan konsumen.

e. Koefisien regresi variabel kepedulian (emphaty) mempunyai arah positif dalam pengaruhnya terhadap kepuasan konsumen .

Dari hasil koefisien regresi berganda yang telah dijelaskan pada uraian diatas selanjutnya akan dilakukan pengujian hipotesis yang dilakukan secara parsial maupun simultan.

\section{KESIMPULAN}

1. Variabel kebutuhan di nilai sangat penting oleh pelanggan SPBU Pasti Pas Meureubo Kabupaten Aceh Barat yang diperoleh dari hasil penyebaran kuesioner terdiri dari 5 variabel yakni variabel tangibles, reliability, responsiveness, Assurance, empathy.

2. Pelayanan di SPBU Pasti Pas Meureubo Kabupaten Aceh Barat sudah memuaskan pelanggannya karena hampir semua variabel kebutuhan yang dinilai memiliki nilai yang bagus.

3. Berdasarkan uji $\mathrm{r}_{\mathrm{Xy}}$ terhadap data menunjukkan bahwa "Ada pengaruh kualitas pelayanan terhadap kepuasan pelanggan pada SPBU Pasti Pas Meureubo Kabupaten Aceh Barat”. Pernyataan tersebut diutarakan karena melihat hasil dari $\mathrm{r}$ hitung lebih besar dari pada $r$ tabel dan pengaruh kualitas pelayanan terhadap kepuasan pelanggan pada SPBU Pasti Pas Meureubo Kabupaten Aceh Barat berada pada kategori sedang. Dengan demikian hipotesi awal yang artinya terdapat pengaruh antara kualitas pelayanan dengan kepuasan pelanggan.

\section{DAFTAR PUSTAKA}

Tjiptono, F., (1997), Total Service Quality, Yogyakarta: Andi Offset.

Stematis, D.H, (1996), Total Quality Service, Principles, Practices, and 
Implementation, Delray Beach: St Lucie Press.

Supranto, J.1992. Pengukuran Tingkat kepuasan Pelanggan.Jakarta : Rineka Cipta.

Supranto, J.1997. Metode Riset Aplikasinya dalam Pemasaran” Jakarta : Rineka Cipta.

Yamit, Zulian.2001. Manajemen Kualitas Produk \& Jasa. Yogyakarta : Ekonesia.

Ginting, Rosnani. 2010. Perancangan Produk. Yogyakarta: Graha Ilmu.

Sheila, S. 2003. Pemetaan dan Evaluasi Kepuasan Konsumen menggunakan Metode Kano berdasarkan Metode Servqual dalam Upaya Mendukung Kualitas Produksi di PT. X.

Parasuraman, A, Berry,LL., Zeithamil, VA., dan Berry, Leonard L, 1988, ”Servqual : A Multiple-Item Scale for Measuring Consumer Perceptions of Service Quality“, Journal of Retailing, Vol. 64, No. 1

Agus Maulana, 2007, Sistem Pengendalian Manajemen. Edisi kelima Jakarta. Penerbit Erlangga.

Muhtosim, Arief. 2006 . Pemasaran Jasa dan Kualitas Pelayanan. Malang :

Bayumedia

Septa, Mayang. 2013. Analisis Pengaruh Kualitas Pelayanan dan Fasilitas Terhadap Kepuasan Pelanggan, Jepara

Karsono. 2006. Pengaruh Pelayanan Terhadap Loyalitas Anggota Dengan Kepuasan Pelanggan Sebagai Variabel Pemediasi,

Pratiwi, Esty Wahyu. 2013. Pengaruh Kualitas Pelayanan SPBU Pasti Pas Terhadap Kepuasan Konsumen Di Kota Malang, Malang.

Ratminto, 2005. Manajemen Pelayanan. Yogyakarta : Penerbit Pustaka Pelajar.

Sarwono. 2006. Metode Penelitian Kuantitatif dan Kualitatif. Yogyakarta :Graha Ilmu.

2005. Prinsip-prinsip Total Quality Service. Yogyakarta: Andi.

Asep M.Ramdan. 2008 Oktober 22. “Hubungan Kualitas Jasa dan kepuasan

Konsumen”. (http://asep-m-ramdan.blogspot.com).

Aviliani, R dan Wilfridus, L. 1997. “Membangun Kepuasan Pelanggan Melalui

Kualitas Pelayanan”. Usahawan, No.5

Singgih Santosa. 2004. SPSS Versi 10 Mengolah Data Statistik Secara

Profesional. Jakarta: PT. Gramedia 